\title{
Relationship between performance measurements and sale price of Dorper rams in the Northern Cape Veld-Ram Club
}

\author{
P.J. Fourie ${ }^{1 \#}$, F.W.C. Neser ${ }^{2}$ and C. van der Westhuizen ${ }^{1}$ \\ ${ }^{1}$ Department of Agriculture, Technikon Free State, Private Bag X20539, Bloemfontein, 9300, Republic of South Africa \\ ${ }^{2}$ Department of Animal Science, University of the Orange Free State, PO Box 339, Bloemfontein, 9300, Republic of South \\ Africa
}

\begin{abstract}
The sale prices of 1609 Dorper rams sold between 1990 and 1999 were compared with their measured performances. An analysis of variance was carried out in order to determine which variables influenced sale price. The most importance factors were classification (stud $v s$. commercial), auction weight and coat type (hair, wool or a mixture). Buyers seem to show a preference for animals with hair and a mixture of hair and wool over those with predominantly woollen coats. Buyers recognise the importance of performance data in the selection of breeding rams.
\end{abstract}

Keywords: Sheep, Dorper, breeding, performance testing.

\# Author to whom correspondence should be addressed; email: pfourie@eng.tofs.ac.za

\section{Introduction}

The need for a breed that was suitable for slaughter lamb production in the arid extensive farming regions of South Africa resulted in the formation of the Dorper breed in the early 1940s. The breed originated from a cross between the Dorset Horn and the Blackhead Persian and has grown to be the second most numerous sheep breed in South Africa (Cloete \& de Villiers, 1987). As the popularity of the Dorper spread to higher rainfall regions, breeding objectives changed from selection for a hardy type of animal with a high percentage of body fat to a type with less body fat. This, together with an increasing tendency to raise animals under intensive conditions, has led to the development of animals with poor adaptability under extensive conditions (Campbell, 1974; Neser et al., 1995). These factors contributed to the creation of veld-ram clubs. In these clubs, Dorper rams (3-6 months of age) from different breeders are performance-tested as a group for 150 days on natural veld, commencing shortly after weaning. Animals are sold at approximately 12 months of age on conclusion of the test period. The breeders remain anonymous at these auctions until the rams have been sold. This keeps the emphasis on the performance of the animal, instead of the breeder (Fourie, 1999). The main advantage is that the buyer is purchasing a ram that has been selected for traits of economic importance and is adapted to the specific environment in which it is expected to perform. The aim of this study was to determine the extent to which the performance of animals in a veld-ram club influences the price buyers are prepared to pay.

\section{Materials and Methods}

The veld type that covers most of the Griqualand West region ( in which the Northern Cape veld-ram club is situated) consists of sweet mixed-bushveld on rocky soil. The rainfall, occurring in summer, ranges from $250 \mathrm{~mm}$ to $350 \mathrm{~mm}$, and is very erratic. In summer, the climate is hot, while the winters are frosty. The underlying rock is dolomite. The grass is by nature tall, dominated by Themeda triandra and Cymbopogon plurinodis, with much Aristida diffusa, Stipagrostis uniplumis, Eragrostis lehmannianaa, Heteropogon contortus, Digitaria eriatha, Chrysopogon serrulatis and Eutachys spp (Acocks, 1988).

The auction prices of 1609 Dorper rams sold between 1990 and 1999 by the Northern Cape veld-ram club were used in the study. Performance data collected included scrotal circumference, Kleiber ratio, auction weight, classification (stud or commercial), coat type (hair, wool or mixture), final weight index, growth per day of age and selection index. The following information was available to the buyer in a catalogue: number of the animal, birth date, test group, scrotal circumference (1990-1999), Kleiber ratio (1990-1997), classification (1990-1999), selection index (1998-1999), final weight index (1993-1995) and growth per day of age index (1996).

Since 1998, stud rams have been defined as animals with above-average conformation and which obtain selection indices of more than 91 during the performance test. These rams should also have a scrotal circumference deviation (deviation from mean) of $\geq-1$. Prior to 1998 stud rams only had to have an above average conformation (type 4 or type 5) and comply with the minimum performance requirements of the test. A commercial ram is an animal with fair conformation and no disqualifications. Commercial rams must also comply with the minimum performance requirements of the test. A merit ram is defined as an animal with above-average conformation and a selection index (since 1998) of more than 115 obtained during the performance test. The scrotal circumference 
deviation of these rams must be at least $1 \mathrm{~cm}$. At the end of the performance test (June) these rams must have at least a type 4 conformation and must also have attained a type 4 or type 5 conformation by the final inspection one week prior to the auction.

Table 1 General statistics of the Northern Cape veld-ram club.

\begin{tabular}{|c|c|c|c|c|c|c|c|c|c|c|}
\hline \multirow[t]{2}{*}{ Year } & \multirow[t]{2}{*}{ Intake } & \multicolumn{2}{|c|}{ Culled on } & \multicolumn{2}{|c|}{ Mean Weight (kg) } & \multirow{2}{*}{$\begin{array}{c}\text { Mean } \\
\text { Scrotal } \\
\text { Circumference } \\
(\mathrm{cm})\end{array}$} & \multicolumn{3}{|c|}{ Sale numbers } & \multirow{2}{*}{$\begin{array}{c}\text { Rams } \\
\text { sold }\end{array}$} \\
\hline & & $\begin{array}{c}\text { Performance } \\
\%\end{array}$ & $\begin{array}{c}\text { Breed } \\
\text { characteristics } \\
\%\end{array}$ & $\begin{array}{c}\text { Beginning } \\
\text { of test }\end{array}$ & $\begin{array}{l}\text { End } \\
\text { of } \\
\text { test }\end{array}$ & & $\begin{array}{c}\text { Commercial } \\
\text { Rams } \\
\%\end{array}$ & $\begin{array}{c}\text { Stud } \\
\text { rams } \\
\%\end{array}$ & $\begin{array}{c}\text { Merit } \\
\text { rams }\end{array}$ & \\
\hline 1991 & 295 & 9 & 28 & 43 & 66 & 33 & 42 & 9 & - & 92 \\
\hline 1992 & 322 & 12 & 31 & 39 & 55 & 31 & 35 & 6 & - & 100 \\
\hline 1993 & 345 & 22 & 15 & 40 & 51 & 31 & 37 & 14 & 1 & 78 \\
\hline 1994 & 280 & 16 & 19 & 39 & 58 & 32 & 39 & 16 & 1 & 94 \\
\hline 1995 & 295 & 18 & 14 & 40 & 58 & 32 & 47 & 10 & 3 & 100 \\
\hline 1996 & 314 & 17 & 10 & 43 & 58 & 32 & 32 & 26 & 1 & 98 \\
\hline 1997 & 333 & 19 & 12 & 41 & 57 & 32 & 38 & 17 & 1 & 100 \\
\hline 1998 & 377 & 8 & 12 & 40 & 54 & 31 & 50 & 5 & 1 & 74 \\
\hline 1999 & 310 & 13 & 12 & 41 & 50 & 27 & 54 & 7 & 0 & 98 \\
\hline
\end{tabular}

From Table 1 it is evident that only 53\% of the rams taken in between 1991 and 1999 were offered for sale at the auction. Only $12 \%$ of the rams taken in qualified as stud rams and only 8 rams qualified as merit rams. Six percent of all animals died, while another six percent were culled on account of reproductive disorders. Average scrotal circumference did not show any significant change over the test period. The low values during 1999 were most probably due to the drought that prevailed during that year. A more complete description of data and management practices in Dorper veld-ram clubs is given by Fourie (1999).

Table 2 indicates that there has been a shift away from woolen coat types to the hairy type and a type with a mixture of hair and wool. This could be ascribed to the perception that the hairy and mixture types are hardier than the woolen coat types. Skins from the hairy and mixture types also fetch higher prices.

Table 2 Distribution of coat type from 1992 to 1996 at the Northern Cape veld-ram club

\begin{tabular}{ccccc}
\hline Year & $\begin{array}{c}\text { Hair } \\
(\%)\end{array}$ & $\begin{array}{c}\text { Mixture } \\
(\%)\end{array}$ & $\begin{array}{c}\text { Wool } \\
(\%)\end{array}$ & Total rams \\
\hline 1992 & 5 & 30 & 65 & 134 \\
1993 & 2 & 29 & 69 & 139 \\
1994 & 11 & 18 & 71 & 156 \\
1995 & 14 & 31 & 55 & 172 \\
1996 & 6 & 39 & 55 & 182 \\
\hline
\end{tabular}

Analyses of variance were carried out to identify variables that significantly influenced sale prices. Sale prices were not normally distributed. It was therefore decided to use log-transformed prices, as this stabilises the variances and results in a better distribution (Mendenhall \& Sincich, 1989). This was followed by a stepwise regression analysis which was carried out to determine the importance of each individual effect on price and to eliminate inter-correlation between effects. The dependant variables for both analyses were scrotal circumference, Kleiber ratio, auction weight, classification (stud or commercial), coat type (hair, wool or mixture), final weight index, growth per day of age and selection index. Each year was analysed separately in order to establish buyer trends over time. Unfortunately, not all factors were measured or presented in the catalogue every year. 
The following model was used in both analyses, and can be considered as descriptive of the data depending on whether the data was measured in a specific year:

$\log (\mathrm{P})=\beta_{0}+\beta_{1}(\mathrm{SC})+\beta_{2}(\mathrm{KR})+\beta_{3}(\mathrm{AW})+\beta_{4}(\mathrm{CL})+\beta_{5}(\mathrm{CC})+\beta_{6}(\mathrm{SI}) \beta_{7}(\mathrm{FWI}) \beta_{8}+(\mathrm{GDOI})+\varepsilon$

where

$\begin{array}{ll}\log (\mathrm{P}) & =\text { log of sale price } \\ \beta_{0} & =\text { constant } \\ \beta_{1}(\mathrm{SC}) & =\text { scrotal circumference }(1990-1999) \\ \beta_{2}(\mathrm{KR}) & =\text { Kleiber ratio }(1990-1997) \\ \beta_{3}(\mathrm{AW}) & =\text { auction weight }(1990-1991 \text { and 1993-1999) } \\ \beta_{4}(\mathrm{CL}) & =\text { classification }(1990-1999) \\ \beta_{5}(\mathrm{CC}) & =\text { coat type }(1992-1996) \\ \beta_{6}(\mathrm{SI}) & =\text { selection index }(1998-1999) \\ \beta_{7}(\mathrm{FWI}) & =\text { final weight index }(1993-1995) \\ \beta_{8}(\mathrm{GDOI}) & =\text { growth per day of age index }(1996) \\ \varepsilon & =\text { error }\end{array}$

\section{Results and Discussion}

The following factors (Table 3) influenced sale price significantly $(\mathrm{P}<0.01)$ : classification, auction weight, coat type, Kleiber ratio, scrotal circumference and final weight index. Rams (stud and commercial) that were larger (higher final weight) at the time of the auction fetched higher prices than smaller rams. Marlow \& Morrow (1967), Sharkey (1982), Lester et al. (1983), Snowder \& Shelton (1985), Fitch et al. (1986), Fowler et al. (1987) and Poggenpoel (1989) have come to a similar conclusion, namely that animals with higher auction weights fetched better prices. Dreyer (1988) reported that Merino rams participating in veld-ram projects with a starting weight exceeding $45 \mathrm{~kg}$ performed worse than lighter animals, although all were sold at the auction due to their higher final weights. Buyers also put a premium on coat type, as there was a preference for animals with hair and a mixture of hair and wool over those with predominantly wool coats. This had a significant influence on sale price in all the years it was measured.

Table 3 Influence of performance data on auction prices from 1990 to 1999 at the Northern Cape veld-ram club.

\begin{tabular}{ccccccccc}
\hline Year & $\begin{array}{c}\text { Scrotal } \\
\text { circumference }\end{array}$ & $\begin{array}{c}\text { Kleiber } \\
\text { ratio }\end{array}$ & $\begin{array}{c}\text { Auction } \\
\text { weight }\end{array}$ & Classification & Coat type & $\begin{array}{c}\text { Selection } \\
\text { index }\end{array}$ & $\begin{array}{c}\text { Final weight } \\
\text { index }\end{array}$ & $\begin{array}{c}\text { Growthper day } \\
\text { of age index }\end{array}$ \\
\hline 1990 & NS & $*$ & $* *$ & $* *$ & 0 & 0 & 0 & 0 \\
1991 & NS & $*$ & $* *$ & $* *$ & 0 & 0 & 0 & 0 \\
1992 & $*$ & NS & 0 & $* *$ & $* *$ & 0 & 0 & 0 \\
1993 & $*$ & NS & $* *$ & $* *$ & $* *$ & 0 & NS & 0 \\
1994 & NS & NS & $*$ & $* *$ & $*$ & 0 & $*$ & 0 \\
1995 & NS & $*$ & $* *$ & $* *$ & $* *$ & 0 & NS & 0 \\
1996 & NS & $*$ & $* *$ & $* *$ & $*$ & 0 & 0 & NS \\
1997 & $*$ & $*$ & $* *$ & $* *$ & 0 & 0 & 0 & 0 \\
1998 & $\mathrm{NS}$ & 0 & $* *$ & $* *$ & 0 & $* *$ & 0 & 0 \\
1999 & $* *$ & 0 & $* *$ & $* *$ & 0 & $* *$ & 0 & 0 \\
\hline
\end{tabular}

$\mathrm{NS}=$ Not significant $; * \mathrm{P}<0.05 ; * * \mathrm{P}<0.01 ; 0=$ Not measured

Scrotal circumference only had a significant influence on auction price in four out of the ten years while classification (stud or flock) had a significant influence over the entire period of the study. Final weight index had a significant influence on sale price in only one of the three years during which it was measured. Growth per day of age index was measured only once, and had no significant influence on sale price. A selection index that included final weight at the end of the test and average daily gain during the test was included in the catalogue during the last two years of the study period. The index had a significant $(\mathrm{P} \leq 0.01)$ influence on sale price in both years.

The results from the stepwise regression analysis presented in Table 4 are similar to that obtained from the analysis of variance. This is an indication that each of the factors has an individual influence on the auction price and that they are not inter-correlated. The result also gives an indication of the relative importance of each individual effect on the price paid for the rams. 
Table 4 Partial contribution (\%) of each factor to the $\mathrm{R}^{2}$ of the model using a stepwise regression analysis on the log-auction price from 1990 to 1999 at the Northern Cape veld-ram club.

\begin{tabular}{cccccccccc}
\hline Year & $\begin{array}{c}\text { Scrotal } \\
\text { circumference }\end{array}$ & $\begin{array}{c}\text { Kleiber } \\
\text { ratio }\end{array}$ & $\begin{array}{c}\text { Auction } \\
\text { weight }\end{array}$ & Classification & $\begin{array}{c}\text { Coat } \\
\text { type }\end{array}$ & $\begin{array}{c}\text { Selection } \\
\text { index }\end{array}$ & $\begin{array}{c}\text { Final weight } \\
\text { index }\end{array}$ & $\begin{array}{c}\text { Growthper day of age } \\
\text { index }\end{array}$ & $\mathrm{R}^{2}$ \\
\hline 1990 & NS & 3.91 & 28.65 & 67.44 & 0 & 0 & 0 & 0 & 0.4174 \\
1991 & NS & 3.36 & 12.86 & 83.78 & 0 & 0 & 0 & 0 & 0.4907 \\
1992 & 5.69 & 3.95 & 0 & 68.28 & 22.11 & 0 & 0 & 0.3799 \\
1993 & 3.75 & 1.38 & 26.10 & 45.76 & 21.72 & 0 & NS & 0.6077 \\
1994 & NS & NS & 37.04 & 44.01 & 11.71 & 0 & 7.26 & 0 & 0.3731 \\
1995 & NS & 6.68 & 36.08 & 53.63 & 3.62 & 0 & NS & 0.6763 \\
1996 & NS & 8.51 & 29.21 & 60.52 & 1.76 & 0 & 0 & 0 & 0.5067 \\
1997 & 3.40 & 1.51 & 68.67 & 26.42 & 0 & 0 & 0 & 0.6036 \\
1998 & NS & 0 & 28.09 & 61.14 & 0 & 10.75 & 0 & 0.5304 \\
1999 & 1.98 & 0 & 58.17 & 20.45 & 0 & 19.40 & 0 & 0.5955 \\
\hline A11
\end{tabular}

All factors included in the table were significant at the $85 \%$ level; NS = Not significant; $0=$ Not measured

Scrotal circumference had little influence on price during the period and was significant in only four out of ten years. The importance of Kleiber ratio varied between years, with its highest contribution during 1996 (8.51\%). Auction weight made the second largest contribution to auction price in all years except for 1997 and 1999 when it made the largest contribution. Classification made the largest contribution to auction price in all the years except for 1997 and 1999 when it made the second largest contribution. Although the contribution of coat type was second largest in 1992, its importance appears to have decreased over time. It would appear that selection index has started to play a more significant role, however, data available for this factor are limited. Final weight index made a significant contribution only once during the three years it was measured. Growth per day of age index made no significant contribution to price.

\section{Conclusions}

Performance as reflected in the selection index appears to play a significant role in determining sale prices. Data for this trait is, however, only available for a very short period, and more data is needed to establish a trend. It is also clear that coat type affected price and buyers were willing to pay a price premium for the more hairy coat types. It is unfortunate that data on coat type were only available up to 1996 , as it is not possible to determine whether this trend has continued. The emphasis put on classification prior to 1998 is, however, remarkable if it is considered that stud rams, as with commercial rams, only had to comply with minimum performance figures. In a certain sense, the buyers at this auction have contrasting breeding objectives and are not consistent in their response to performance data. Van der Westhuizen (1997) reported that farmers with predominantly livestock enterprises have shown a vast improvement with regard to the execution of production planning processes concerned with the formulation of breeding objectives, and with regard to their knowledge of breeding deficiencies. However, buyers are still willing to pay more for rams that exhibit the desired breed characteristics. Consequently the breeder is obliged to breed animals that will not only satisfy buyers as far as breed standards are concerned, but animals which also have the necessary performance figures.

\section{Acknowledgements}

The authors wish to thank J.M. Van Zyl for the statistical analysis of data.

\section{References}

Acocks, J.P.H., 1988. Veldtypes of South Africa. $3^{\text {rd }}$ ed. Memoirs of the Botanical Survey of South Africa, No. 57. Botanical Research Institute, Department of Agriculture and Water Supply. Government Printer, Pretoria.

Campbell, Q.P., 1974. A study of breeding problems in the Dorper sheep. D.Sc.Thesis, U.O.F.S., Bloemfontein.

Cloete, S.W.P. and De Villiers, T.T., 1987. Production parameters for a commercial Dorper flock on extensive pastures. S. Afr. J. Anim. Sci. 17, 121.

Dreyer, C.J., 1988. Veld-ram clubs. Merino Breeders J. January-June, 1988.

Fitch, G.Q., Butler, J.G., Golden, B.L., and Denham, A.H., 1986. Identification of characteristics influencing sales price on performance-tested ram lambs. J. Anim. Sci. 63 (Suppl.1), 212 (Abstr.)

Fourie, P.J., 1999. 'n Kritiese evaluasie van Dorper-veldramprojekte in Suid-Afrika. M.Tech. verhandeling, Technikon Vrystaat, Bloemfontein.

Fowler, K.F., Baertsche, S.R. and Davis, M.E., 1987. An evaluation of the factors affecting sales price in performance-tested rams. Sheep Indust. Dev. Res. Digest. 3(2), 19. 
Lester, D.C., Notter, D.R. and McClure, W.H., 1983. Factors affecting sale price of performance-tested yearling rams. J. Anim. Sci. 57 (Suppl. 1), 47 (Abstr.)

Marlow, T.J. and Morrow, G.A., 1967. Factors influencing the sale price of R.O.P. bulls. J. Anim. Sci. $26,205$.

Mendenhall, W. and Sincich, T., 1989. A second course in business statistics, third edition. Dellen Publishers, San Francisco.

Neser, F.W.C., Konstantinov, K.V. and Erasmus, G.J., 1995. Estimated genetic trends for weaning weight in three Dorper lines with different selection criteria. S. Afr. J. Anim. Sci. 25, 65.

Poggenpoel, D.G., 1989. Verband tussen prestasiemetings en veilingspryse van Veldmerinoramme. S. Afr. Tydskrif. Veekunde 19(1), 50.

Sharkey, D.M., 1982. Factors affecting the sale price of central performance-tested beef bulls and the estimation of genetic and environmental trends. Ph.D. Dissertion, Ohio State University.

Snowder, G.D. and Shelton, M., 1985. Factors affecting sales price of performance-tested Rambouillet rams. Sheep. Indust. Dev. Res. Digest 2(1), 6.

Van der Westhuizen, C., 1997. Veranderinge in bestuurspraktyke van kommersiële boere in Suider-Afrika en die implikasie vir boerderybestuursopleiding by technikons. Ph.D. tesis, U.O.V.S., Bloemfontein. 